\title{
THE POLAR OUTBREAK IN MID-DECEMBER
}

\author{
LLOYD W. CHAMBERLAIN AND CHARLOTTE L. ROE
}

WBAN Analysis Center, U. S. Weather Bureau, Washington, D. C.

\section{INTRODUCTION}

Cold air associated with a large Arctic anticyclone entered the United States on December 16, 1953, bringing well below normal temperatures to the North Central and Southeastern States. Very large scale cyclonic circulation covering most of the area from $30^{\circ}$ to $60^{\circ} \mathrm{N}$. and $50^{\circ}$ to $90^{\circ} \mathrm{W}$. and extending through all levels, coupled with large-amplitude ridging aloft westward, contributed to the deep southward penetration of the cold air. A few of the interesting aspects of this anticyclone, which for convenience we shall call "Echo", will be discussed and also compared with features of the potential cold outbreak at the end of the month.

\section{SYNOPTIC FEATURES}

Cooling of the surface layer of air by radiation of its heat to the underlying snow- and ice-covered Arctic surface, apparently contributed to the building of Echo by the process described by Wexler [1]. Echo first appeared on the surface December 11 with a 1016-mb. central pressure near $75^{\circ} \mathrm{N}$., $120^{\circ} \mathrm{W}$. From about the same latitude on December 12, Echo started its southsoutheastward journey pausing at about $60^{\circ} \mathrm{N}$. until its central pressure reached $1035 \mathrm{mb}$. on December 15 (fig. 1). From this latitude and $100^{\circ} \mathrm{W}$., the cell moved southward, slowly curving more to the south-southeast, with an average speed of 25 knots. The highest pressure noted on 6-hourly charts was $1042 \mathrm{mb}$. on December 17 in southern Iowa. From a position in nortbwest Alabama on December 18, the track became more easterly, and on the 19th Echo moved out into the Atlantic still maintaining a central pressure of $1030 \mathrm{mb}$. The track is shown in figure 2 and also on Chart IX.

According to the classification suggested by James [2], Echo was not an intense anticyclone until it reached the latitude of Iowa ; it remained so until it moved off the east coast 3 days later.

This December polar outbreak was spectacular not for record high pressures or low temperatures, but more for the ease with which it penetrated far southward. The surface and 500-mb. charts for this period show that the High followed the path of least resistance between a Low to the east and a ridge to the west. Figures 1 and 3 show the large scale circulation at the surface and at $500 \mathrm{mb}$. on December 15. The Low in Quebec, beginning as a wave in the Gulf of Mexico on December 13, had moved northeastward to the east of the Appalachians and deepened to a central pressure of $975 \mathrm{mb}$. by December 15 . This main Low was reinforced by a weak Low that had moved southeastward from Alberta and by December 16 (fig. 2) had lost its own closed circulation in the peripheral circulation of the deeper storm. When Echo started southward, most of the area between $30^{\circ}-60^{\circ} \mathrm{N}$. and $50^{\circ}-90^{\circ} \mathrm{W}$. was under the influence of very large scale cyclonic circulation at all levels. The semi-permanent $500-\mathrm{mb}$. elongated Low just off the west coast of Greenland served as a focal point for the cyclonic circulation aloft. A trough extended essentially north-south from this Low to the eastern Gulf of Mexico. In middle latitudes this trough had proceeded eastward at about 40 knots.

Simultaneously most of the United States had been influenced by the Great Basin High and by an $\mathrm{mP}$ High which had migrated east-southeastward to the western Gulf of Mexico by December 15. By $1830 \mathrm{GMT}$ December 16, when Echo had passed into Minnesota, most of the western United States and Canada was covered with high pressure. The surface ridge line extended north-northwest-south-southeast from the Yucatan Peninsula through central United States to northwestern Canada (fig. 4). Aloft most of western United States and Canada showed the anticyclonic circulation and increasing amplitude of the 500-mb. ridge which extended north-south near the 120 th meridian.

Another large scale feature (fig. 1 and 3) was the deep Low in the Gulf of Alaska. It reached a depth of 961 $\mathrm{mb}$. at 1230 GMT December 14 . At $500 \mathrm{mb}$. this circulation was centered near $50^{\circ} \mathrm{N}$., $160^{\circ} \mathrm{W}$.

\section{VERTICAL STRUCTURE}

Wexler [3] points out that in North America the polar anticyclone is characterized by a troposphere colder than its environment, especially in the lower portion, and a low $\left(5\right.$ to $8 \mathrm{~km}$.) warm $\left(-50^{\circ} \mathrm{C}\right.$. to $-65^{\circ} \mathrm{C}$.) tropopause and warm lower stratosphere, while the warm anticyclone may have a thin cold layer at the surface, a warm troposphere, a high $\left(12\right.$ to $17 \mathrm{~km}$.) cold $\left(-65^{\circ} \mathrm{C}\right.$. to $-80^{\circ} \mathrm{C}$.) tropopause and a cold lower stratosphere. As Echo started its southward plunge from a point west of Church- 


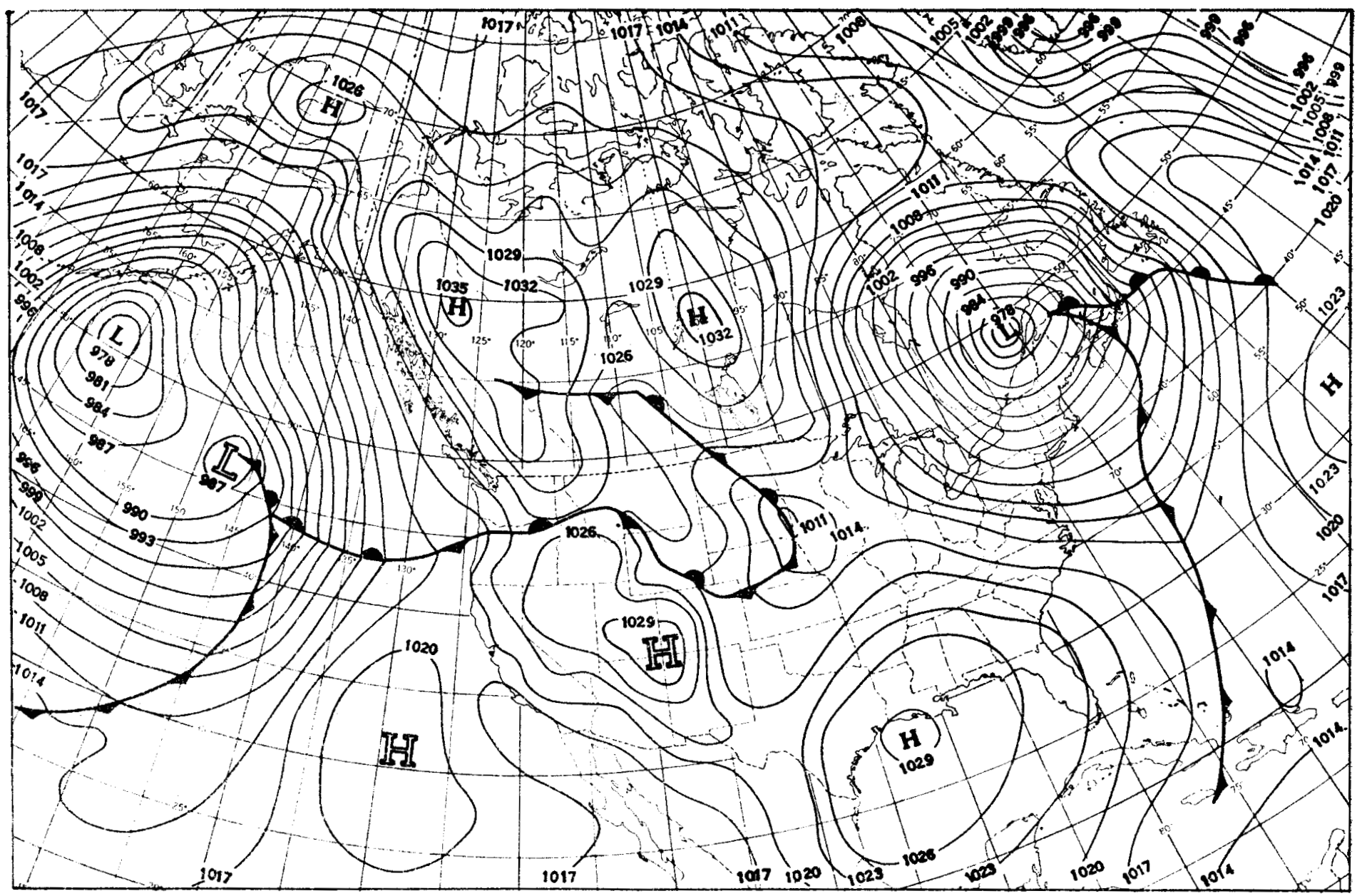

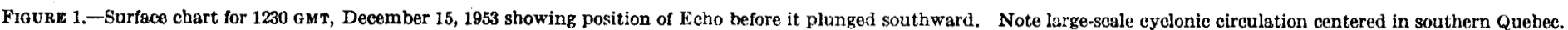

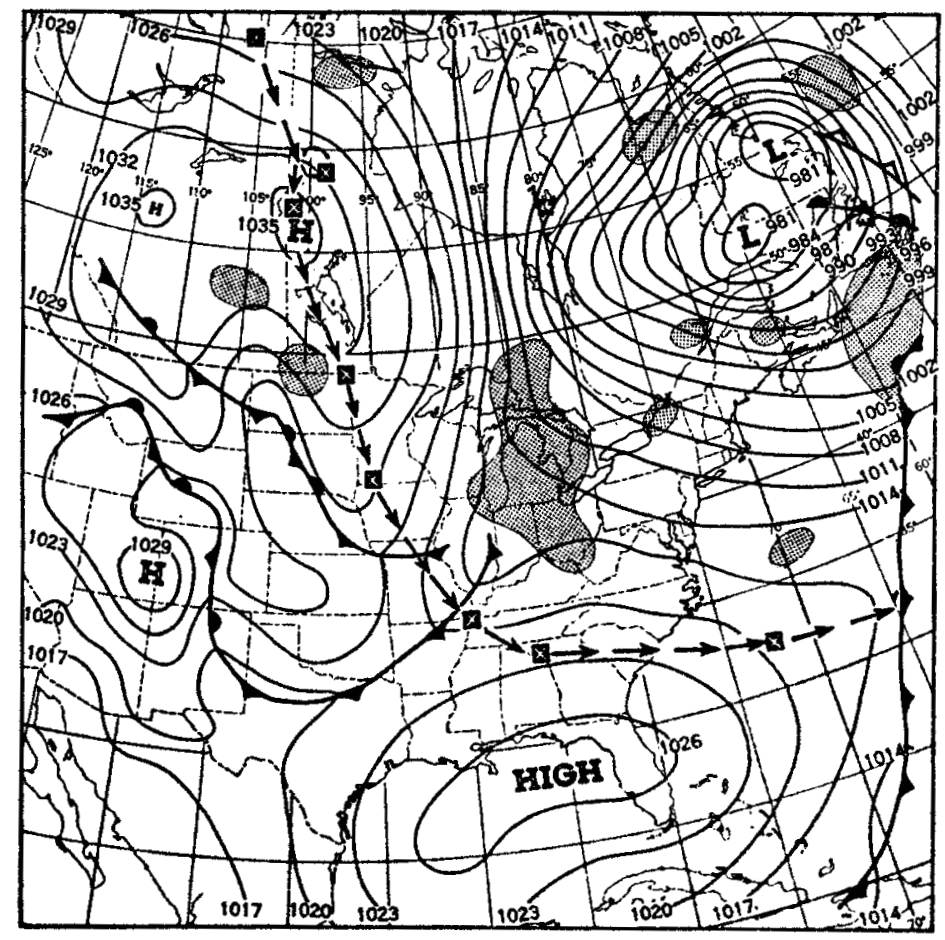

Figure 2.- Surface chart for C030 oxt, December 16, 1953 showing oomplete track of Echo. 24-hour positions of center from $1230 \mathrm{oxr}$ December 13 to $1230 \mathrm{GKr}$ December 20 inclusive are marked by an " $X "$ ". Shading shows areas of active precipitation. ill, Manitoba, its characteristics met the cold High requirements shown by Wexler. Churchill's sounding at 0300 GMT, December 15 (fig. 5A) shows a shallow cold surface layer, and a warm $\left(-49^{\circ}\right.$ C.), low $(7.2 \mathrm{~km}$.) tropopause. By $0300 \mathrm{GMT}$, December 16 when the center of cold air had moved to the south, Churchill showed a colder $\left(-55^{\circ} \mathrm{C}\right.$.) and higher $(8.5 \mathrm{~km}$.) tropopause. However, at International Falls, Minn., throughout the period, the lowest tropopause recorded was $330 \mathrm{mb}$. $(8.5 \mathrm{~km}$.) (fig. $5 \mathrm{~B})$. At that time the polar characteristics showed slight modification and when the High center approached Nashville, Tenn. (fig. 6), the lowest tropopause shown was $240 \mathrm{mb}$. (above $10 \mathrm{~km}$.). The Nashville sounding at 0300 gмт, December 19 (fig. 5C) showed $10^{\circ}$ to $15^{\circ} \mathrm{C}$. of warming throughout most of the troposphere ducing the 24-hour period while Nashville was located within the central isobar of Echo.

\section{TEMPERATURE FIELD}

The 1000- to $500-\mathrm{mb}$. thickness chart for $1500 \mathrm{aMT}$, December 15 (fig. 7) shows an extensive area of cold advection east of $115^{\circ} \mathrm{W}$. and from Canada to the Gulf of Mexico. This is one example that illustrates how cold air could be extrapolated with the $500-\mathrm{mb}$. flow as an aid to forecasting the cold outbreak penetrating the southern 


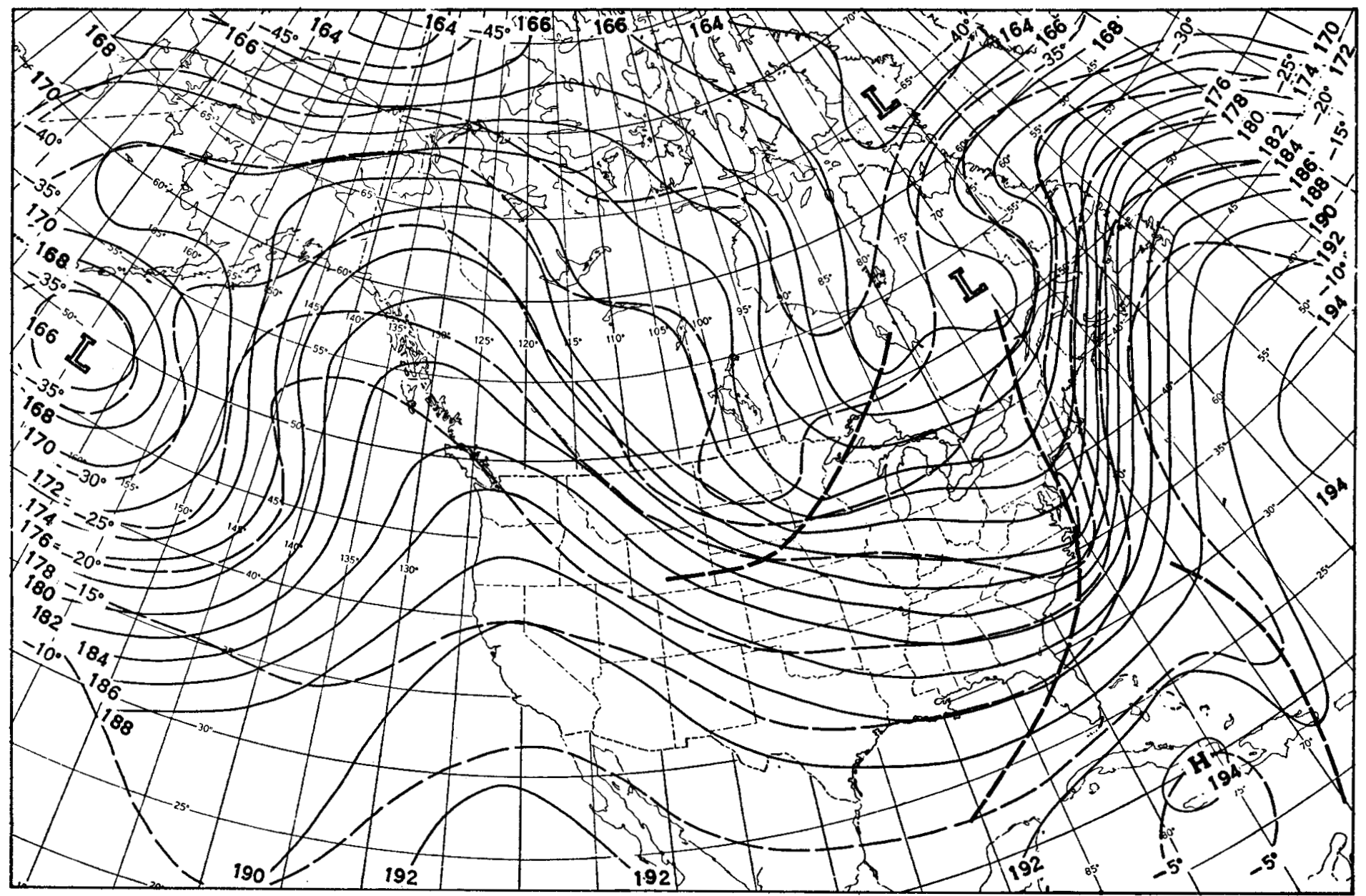

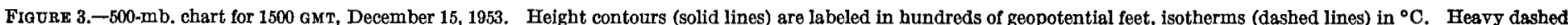
lines indicate troughs. Note ridge over Alaska and northwestern Canada and northwest flow from western Canada to the southeastern United States.

States (fig. 8). A comparison with a potential polar outbreak on December 28 using the above point will be made later.

In connection with this cold outbreak, the 1000- to $500-\mathrm{mb}$. thickness departure from normal is of interest. Figure 9 shows above and below normal thickness areas for $1500 \mathrm{GMT}$, December 18, and the advancing positions of the minus $400-\mathrm{ft}$. thickness departure contour from 1500 GMT December 15 to 1500 GMT, December 18 . The departure gradient points out a region of strong temperature contrast from $95^{\circ} \mathrm{W}$. to $75^{\circ} \mathrm{W}$. and from the Gulf of Mexico to Canada. As a 400-ft. thickness departure from normal is equivalent to an $11^{\circ} \mathrm{F}$. departure from normal of the mean virtual temperature for the 1000- to $500-\mathrm{mb}$. layer, the data in figure 9 may be compared with observed temperature departures. Table 1, listing surface minimum temperatures and departures from normal, shows that surface drops in some places far exceeded the mean virtual temperature drop for the $1000-$ to $500-\mathrm{mb}$. layer. Although only one record was broken (Lexington, Ky.), the departure from normal ranged from $-12^{\circ}$ to $-25^{\circ} \mathrm{F}$. Note that the highest pressure and minimum temperature for the month for most of these stations occurred on approximately the same day.

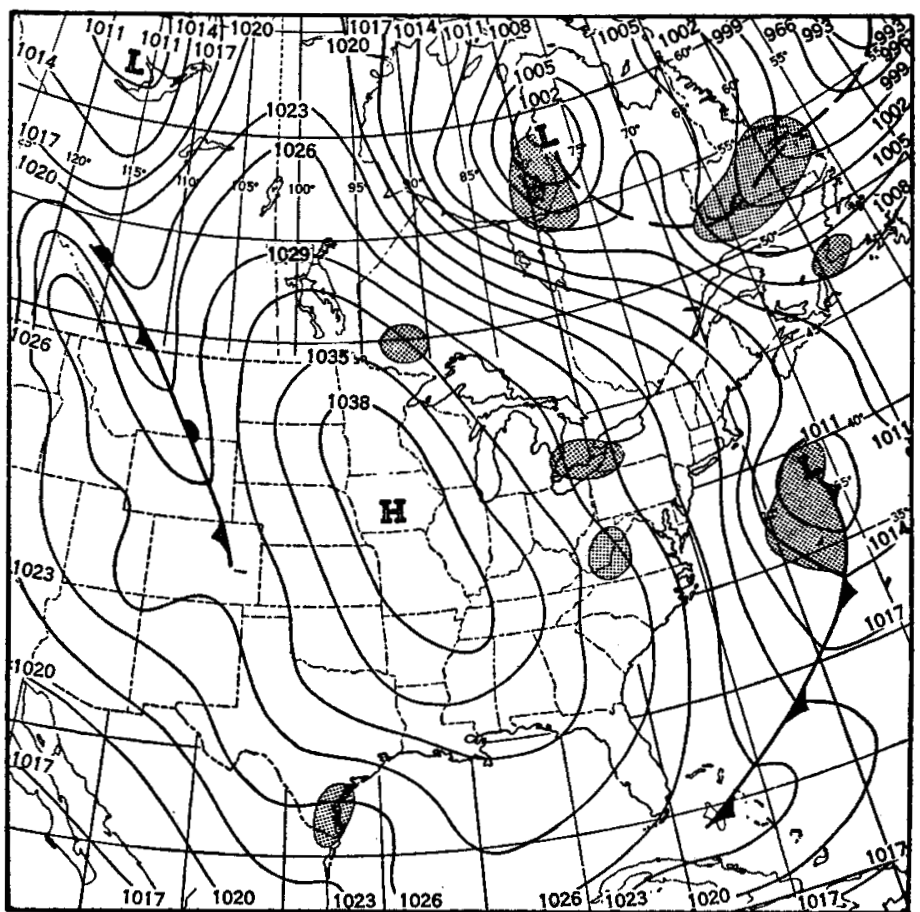

Fig URE 4.--Surface chart for 1230 GMT, December 17, 1953 showing most of the United States under the influence of Echo. Shading shows areas of active precipitation. 

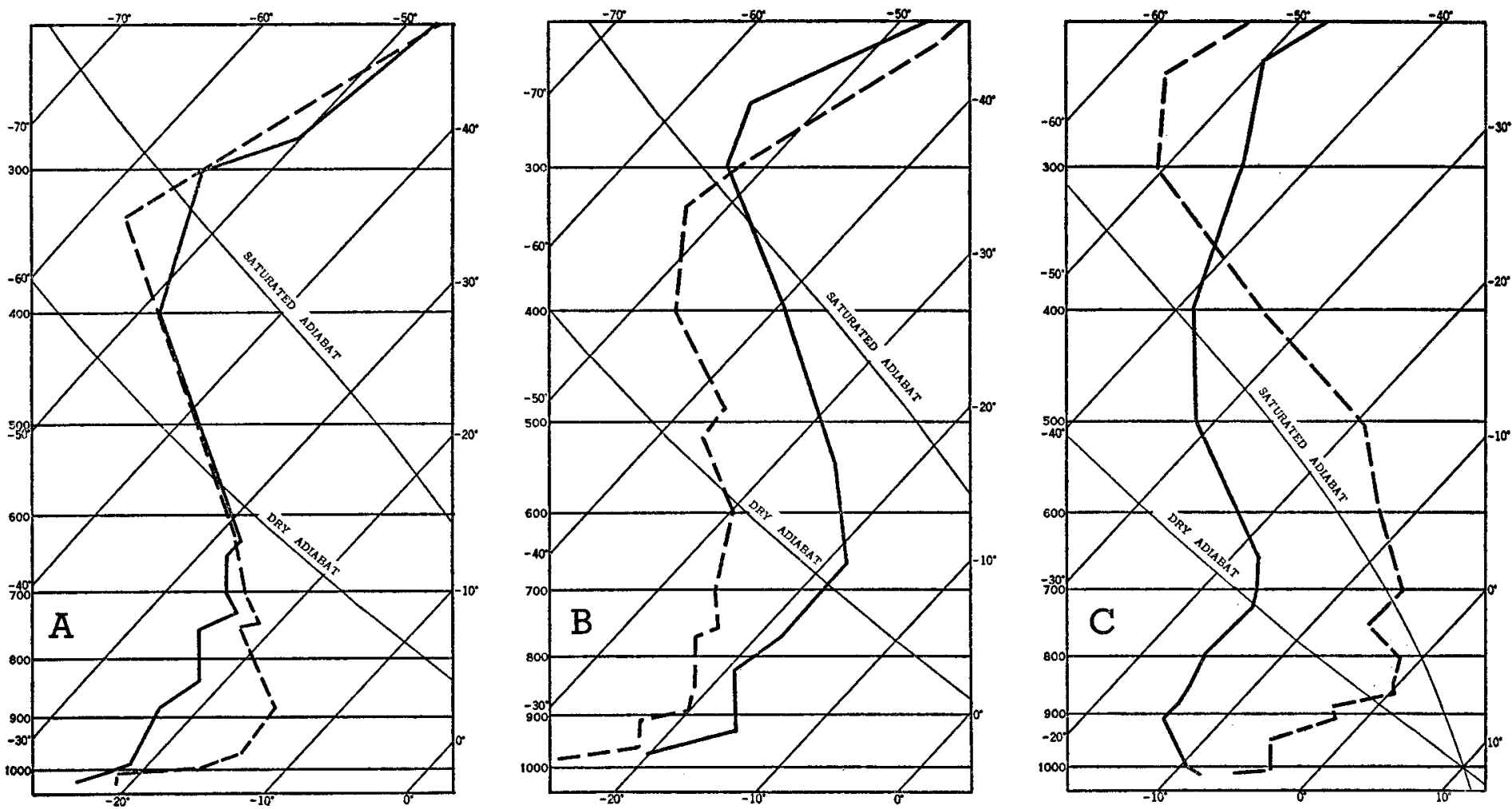

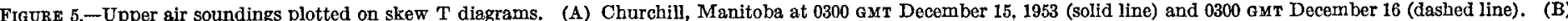

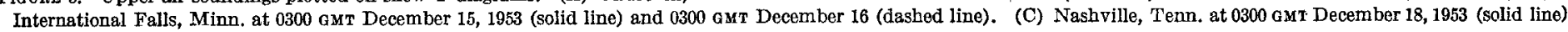
and $0300 \mathrm{GMT}$ December 19 (dashed line).

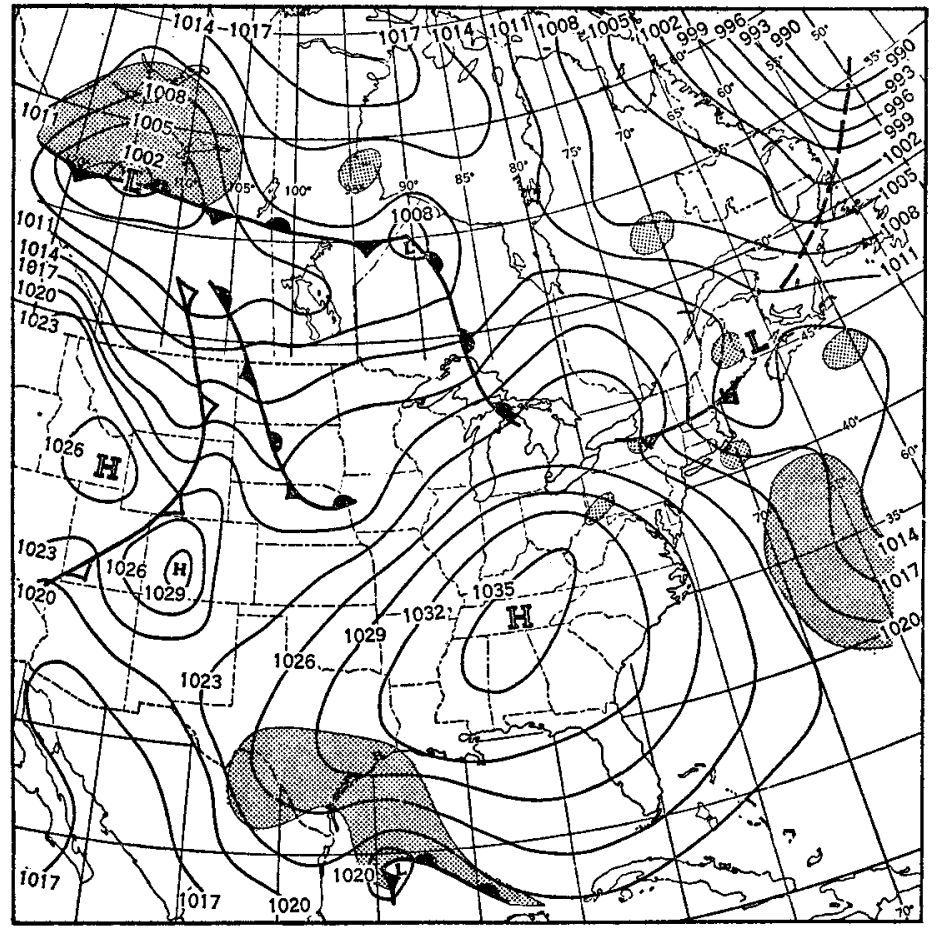

FiguRe 6.-Surface chart for 0030 GMT December 19, 1953. Shading shows areas of active precipitation.

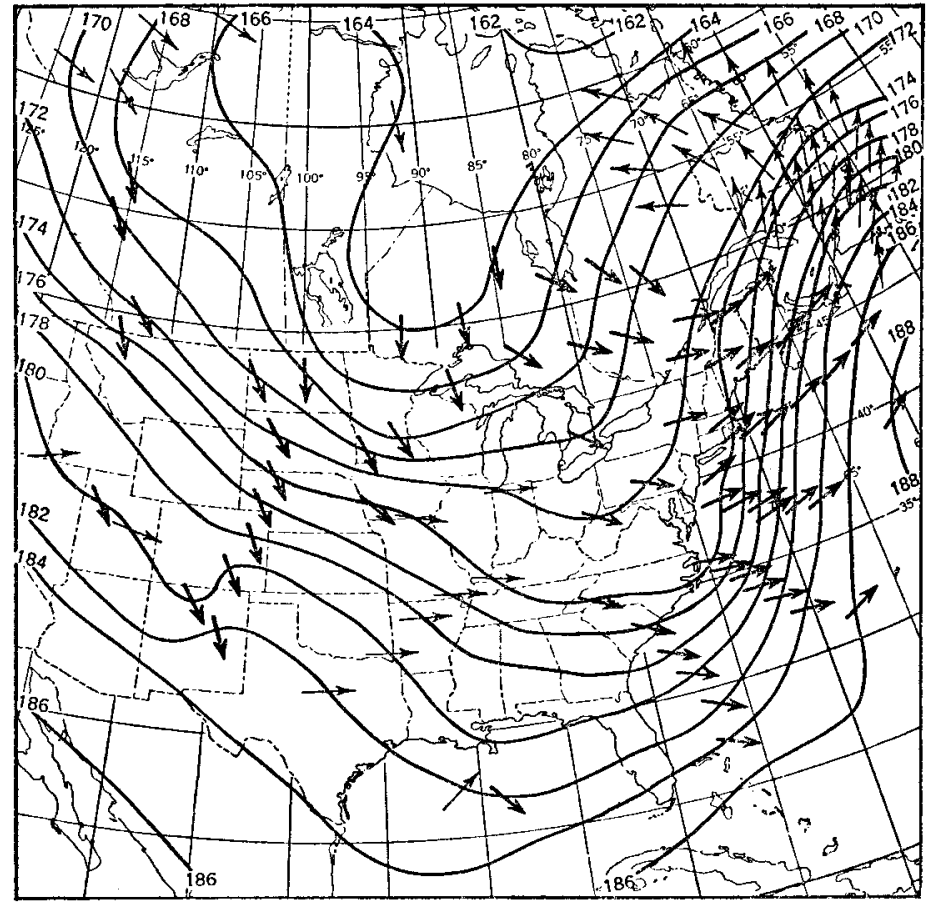

FIgURe 7.-1000- to 500-mb. thickness chart for 1500 GMT, December 15, 1953. Thickness, labeled in hundreds of feet, is proportional to mean virtual temperature. Advection arrows (thin shaft $=$ warm advection, thick shaft $=$ cold advection) are obtained from mean flow against 1000 - to $500-\mathrm{mb}$. thickness lines. 


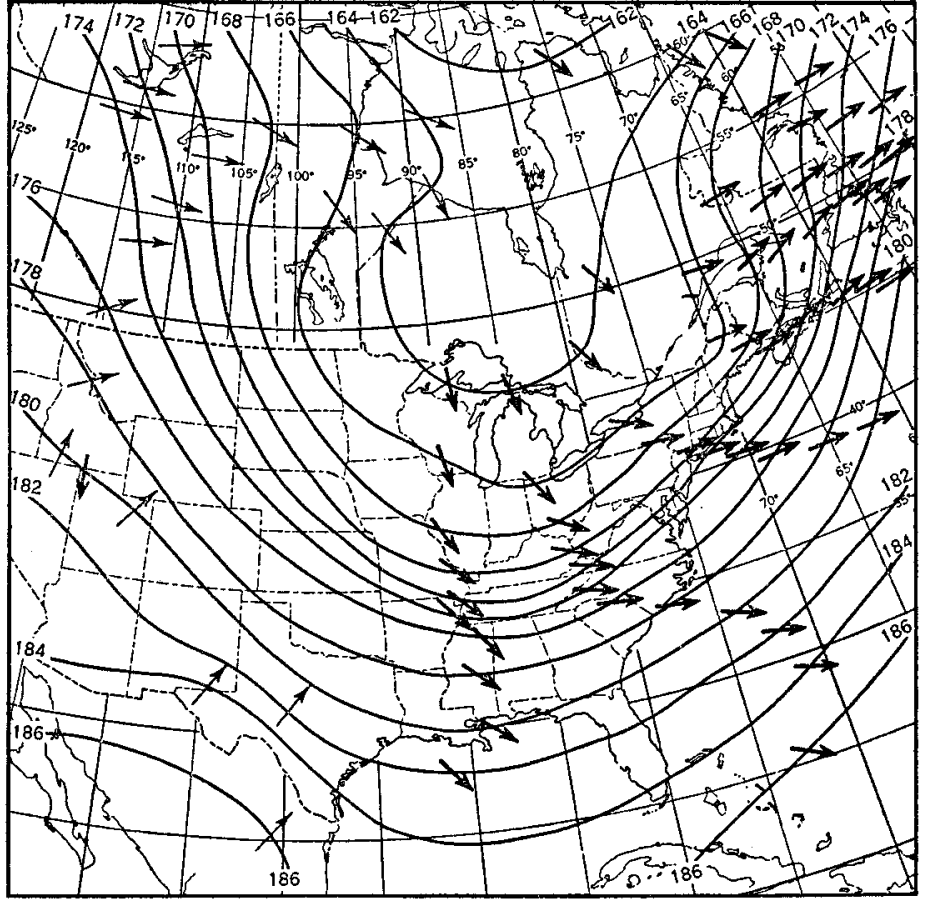

FIGURE 8.-1000- to 500-mb, thickness chart for 1500 GMT December 16, 1953 . Compare with figure 7 and note southward and eastward progression of cold advection (thick shaft) arrows.

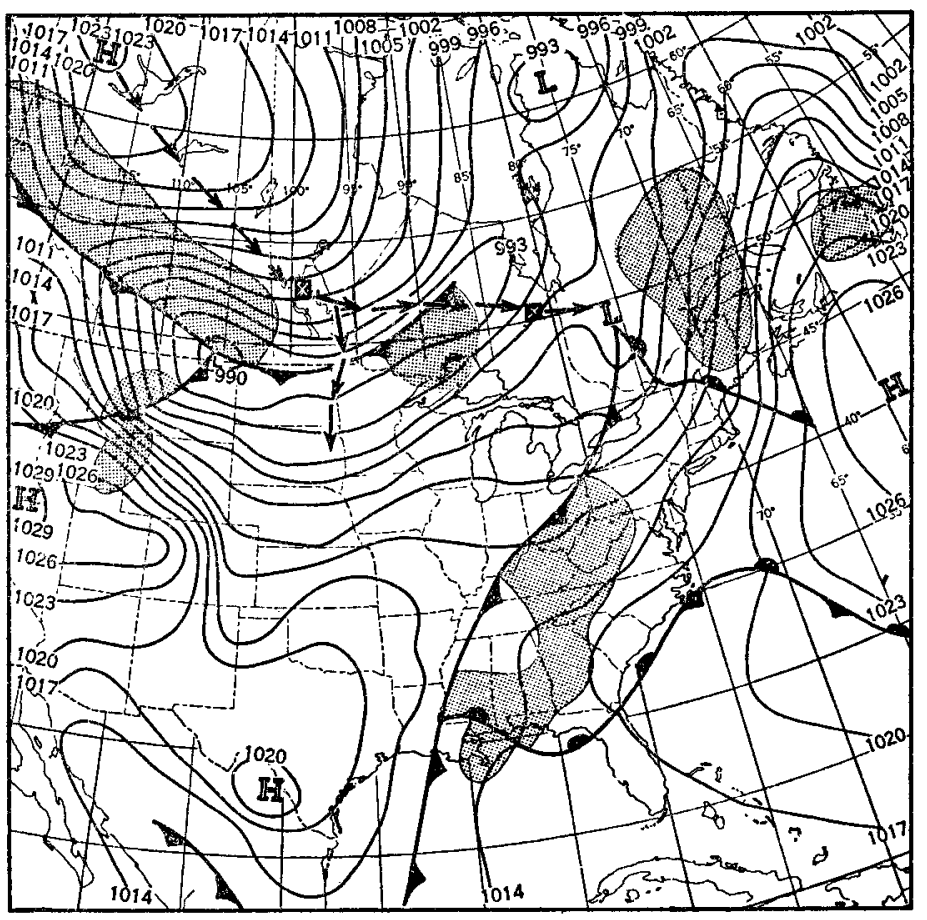

FIGURE 10.--Surface chart for 1830 aMT, December 28,1953 showing track of Fox on succeeding days. " $\mathrm{X}$ " marks position at 24 -hr. intervals. Shading shows areas of active precipitation.

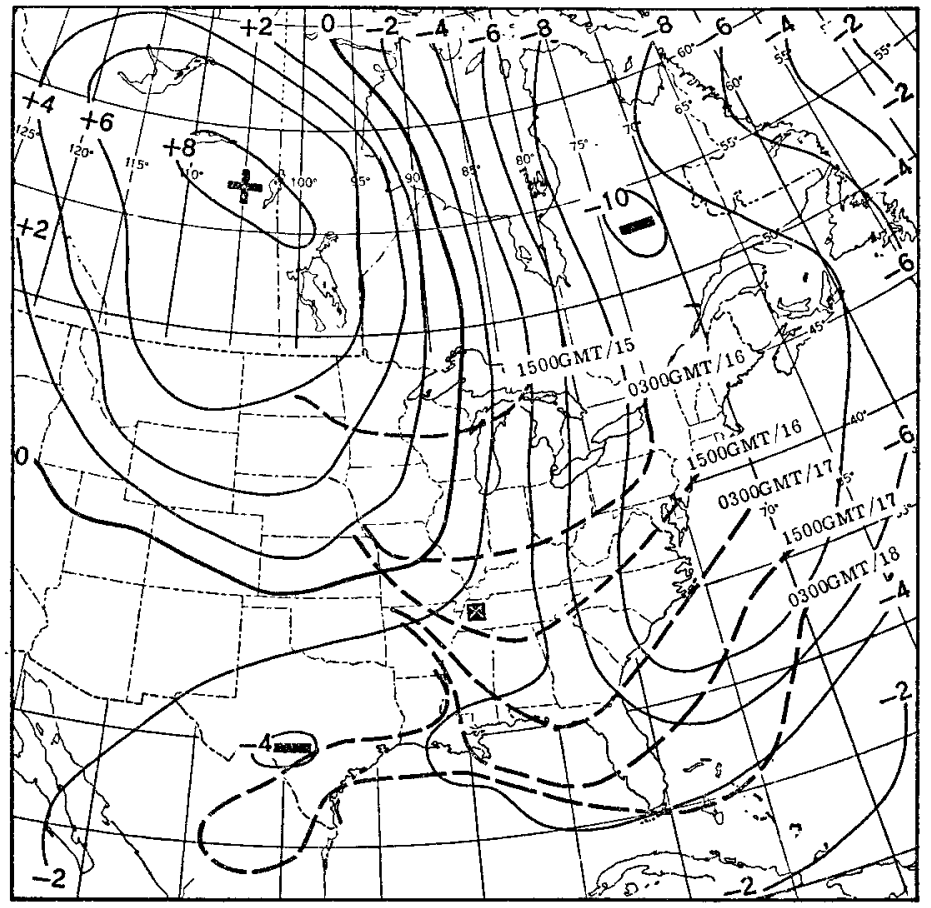

FiguRe 9.-Departure from normal 1000- to $500-\mathrm{mb}$, thickness chart (labeled in hundreds of feet) for $1500 \mathrm{GMT}$, December 18, 1953. " $\mathrm{X}$ " marks surface position of Echo at this time. Heavy dashed lines give position of minus 400 -ft. departure from norma contour at 12-hr. Intervals from $1500 \mathrm{GMT}$, December 15 to $0300 \mathrm{GMT}$ December 18 inclusive showing its southward progression.

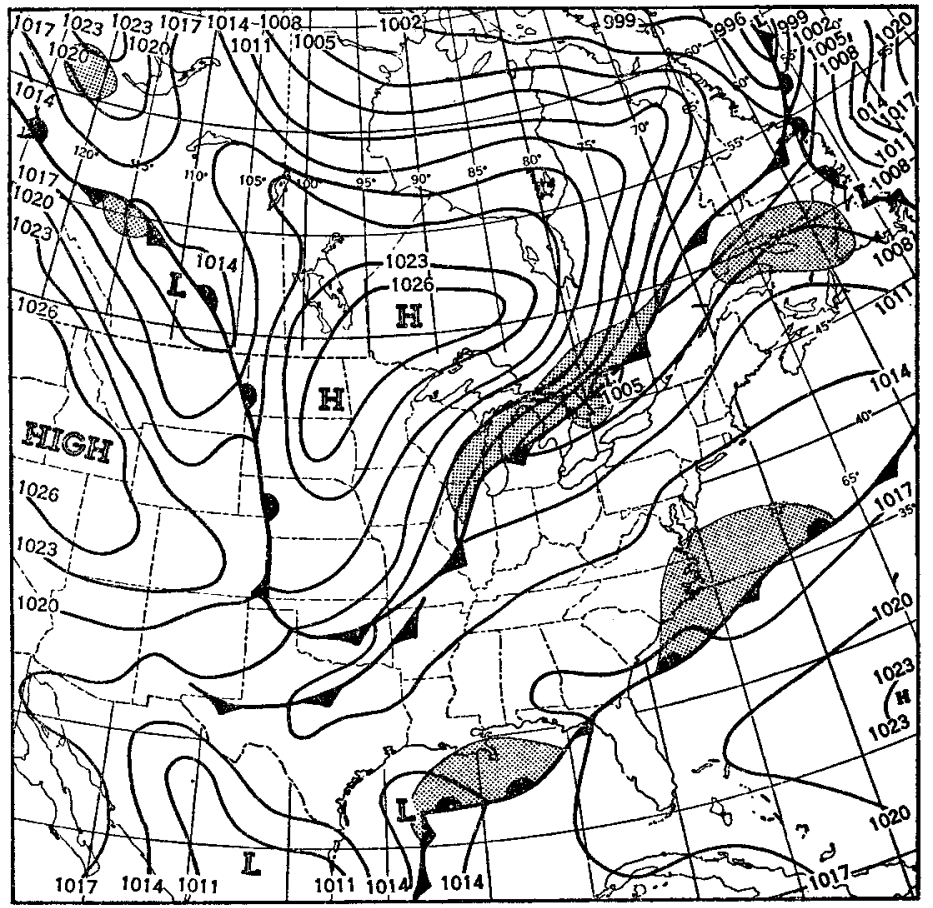

Fig URE 11.--Surface chart for 0030 GMT, December 30 when Fox showed signs of splitting into two cells. Shading shows areas of active precipitation. 


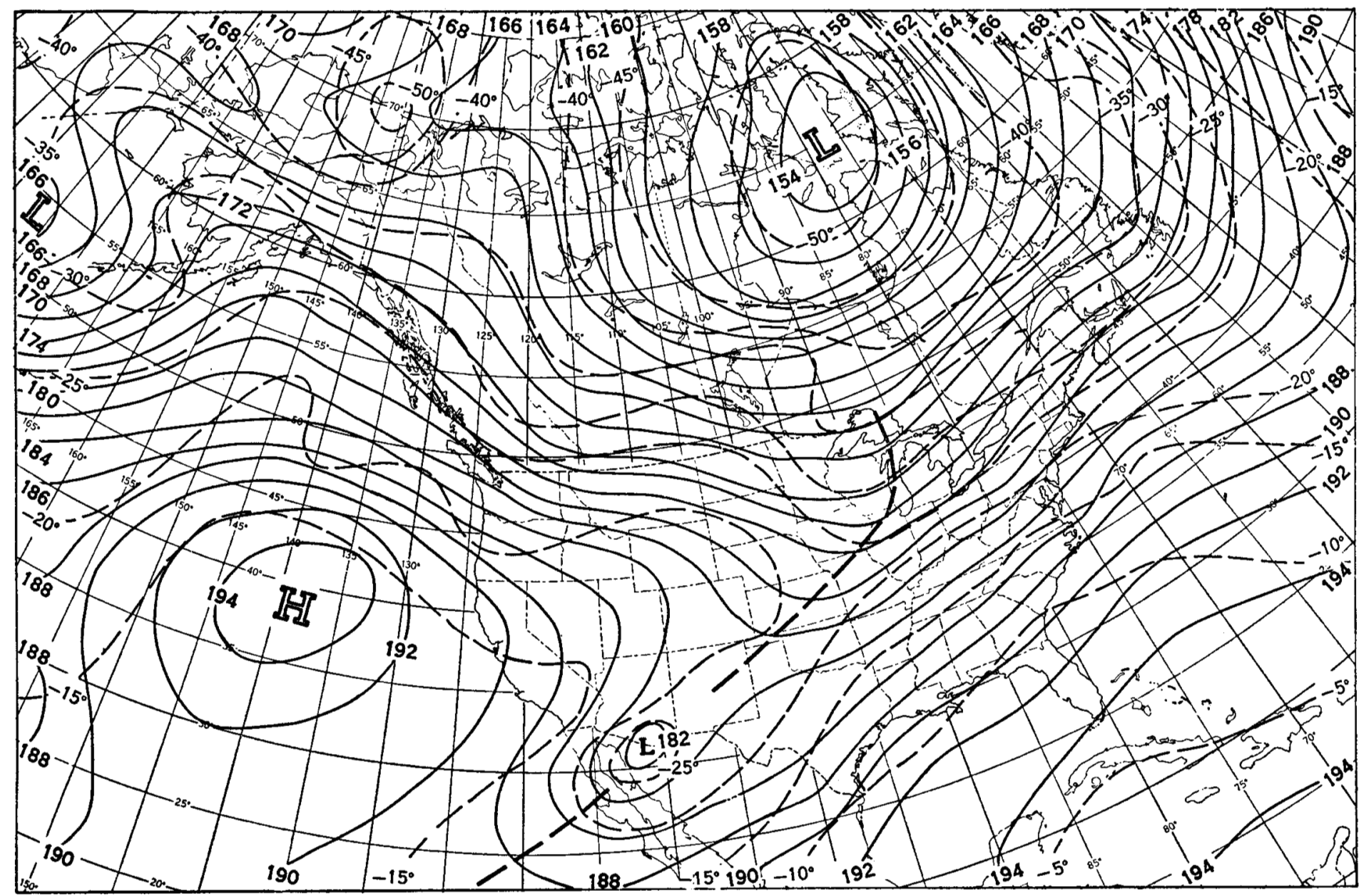

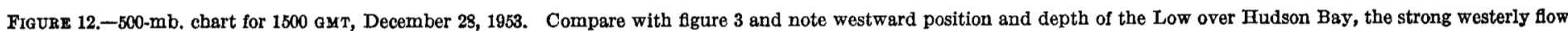
from $45^{\circ}$ to $60^{\circ} \mathrm{N}$, and the position of the High in the eastern Pacific.

TABLE 1.-Minimum temperatures and departures from normal, and highest pressure at selected stations, December 1953

\begin{tabular}{|c|c|c|c|c|c|c|}
\hline \multirow[b]{2}{*}{ Station } & \multicolumn{3}{|c|}{ Surface temperature } & \multicolumn{2}{|c|}{$\begin{array}{l}\text { Sea level } \\
\text { pressure }\end{array}$} & \multirow[b]{2}{*}{ Remarks } \\
\hline & Date & $\begin{array}{l}\text { Min. } \\
\text { for } \\
\text { month } \\
\text { ( F.) }\end{array}$ & $\begin{array}{c}\text { Depar- } \\
\text { ture from } \\
\text { normal } \\
\left({ }^{\circ} \mathrm{F} .\right)\end{array}$ & Date & $\mid \begin{array}{c}\text { Highest } \\
\text { for } \\
\text { month } \\
\text { (mb.) }\end{array}$ & \\
\hline $\begin{array}{l}\text { Birmingham, Ala } \\
\text { Mobile, Ala, Ala } \\
\text { Jacksonvile, Fla } \\
\text { Miami, Fla } \\
\text { Tampa, Fla } \\
\text { Atlanta, Ga } \\
\text { Savannah, Ga. } \\
\text { Chicago, lll } \\
\text { Lexington, Ky } \\
\end{array}$ & $\begin{array}{r}18 \\
18,19 \\
18 \\
18,19 \\
18 \\
18 \\
19 \\
18 \\
17,18\end{array}$ & $\begin{array}{r}14 \\
27 \\
26 \\
45 \\
36 \\
13 \\
17 \\
0 \\
0\end{array}$ & $\begin{array}{r}-21 \\
-19,-13 \\
-14,-12 \\
-18 \\
-18 \\
-21 \\
-19 \\
-14 \\
-25,-22\end{array}$ & $\begin{array}{l}18 \\
18 \\
18 \\
-18 \\
18 \\
18 \\
17 \\
18\end{array}$ & \begin{tabular}{|l|}
1039.3 \\
1037.6 \\
1034.9 \\
1033.5 \\
1037.6 \\
1035.6 \\
1033.9 \\
1038.3
\end{tabular} & City office. \\
\hline $\begin{array}{l}\text { Baltimore, Md } \\
\text { Jackson, Miss }\end{array}$ & $\begin{array}{l}18 \\
18\end{array}$ & $\begin{array}{l}15 \\
22\end{array}$ & $\begin{array}{l}-14 \\
-12\end{array}$ & $\begin{array}{l}24 \\
18\end{array}$ & $\begin{array}{l}1032.2 \\
1039.3\end{array}$ & Not lowest min. for \\
\hline $\begin{array}{l}\text { Charlotte, N. C } \\
\text { Hatteras, N. C. } \\
\text { Dayton, Ohio... }\end{array}$ & $\begin{array}{l}18 \\
18 \\
18\end{array}$ & $\begin{array}{r}11 \\
27 \\
-3\end{array}$ & $\begin{array}{l}-20 \\
-18 \\
-23\end{array}$ & $\begin{array}{l}18 \\
19 \\
18\end{array}$ & \begin{tabular}{l|}
1035.2 \\
1032.9 \\
1035.6
\end{tabular} & $\begin{array}{l}\text { Min. temp. coldest } \\
\text { since Dec. } 16,1951 \text {, } \\
\text { when }-15 \text { recorded. }\end{array}$ \\
\hline $\begin{array}{l}\text { Philadelphia, Pa... } \\
\text { Columbia, S. C } \\
\text { Charleston, S. C- } \\
\text { Nashville, Tenn } \\
\text { Elkins, W. Va. } \\
\text { Washington, D. } \\
\end{array}$ & $\begin{array}{l}18 \\
18 \\
19 \\
18 \\
19 \\
18\end{array}$ & $\begin{array}{r}14 \\
12 \\
16 \\
9 \\
0 \\
17\end{array}$ & $\begin{array}{l}-13 \\
-22 \\
-18 \\
-21 \\
-14 \\
-14\end{array}$ & $\begin{array}{l}24 \\
18 \\
19 \\
18 \\
24 \\
24\end{array}$ & $\mid$\begin{tabular}{l|}
1030.5 \\
1036.2 \\
1035.2 \\
1039.6 \\
1034.5 \\
1032.8
\end{tabular} & $\begin{array}{l}\text { Columbia Airport. } \\
\text { Municipal airport. }\end{array}$ \\
\hline
\end{tabular}

POTENTIAL POLAR OUTBREAK OF DECEMBER 28-31

At 1830 GMT, December 28 an Arctic anticyclone appeared as a $1024-\mathrm{mb}$. cell centered about $65^{\circ} \mathrm{N}$., $125^{\circ} \mathrm{W}$. oriented northwest-southeast (fig. 10). This anticyclone, which will be referred to as "Fox", moved southeastward at about 45 knots. By 1830 GMT December 29, Fox, with a central pressure of $1029 \mathrm{mb}$. was centered about 100 miles north of the western Minnesota-Canadian border. Six hours later (fig. 11) surface data indicated the beginning of the splitting of Fox with one center moving southward and one eastward. The southward portion of Fox was small and did not bring very cold temperatures south of Iowa. The eastbound portion was more intense and brought colder temperatures eastward along the Canadian border before curving more northeastward.

At 1830 GMT, December 28 (fig. 10), the main Low in the east (not shown) was near $70^{\circ} \mathrm{N}$. and just west of Greenland with a secondary center about $60^{\circ} \mathrm{N}$., $80^{\circ} \mathrm{W}$. A weak, rapidly moving, 1001-mb. Low, centered in southern Quebec, had formed 60 hours earlier in Alberta. 
Its track had been generally west to east dipping into the United States in the Dakotas and Minnesota. A third Low was centered along the eastern Montana-Canadian border. At the same time western and south central United States were influenced by an eastern wedge of the main Pacific High which was centered at $40^{\circ}$ N., $135^{\circ} \mathrm{W}$. and dominated the circulation from the west coast to $155^{\circ} \mathrm{W}$. and from $15^{\circ} \mathrm{N}$. to the southern Alaskan coast.

A deep, 15,300-ft. Low near $65^{\circ} \mathrm{N}$., $80^{\circ} \mathrm{W}$. was the center of extensive cyclonic circulation at $500 \mathrm{mb}$. at 1500 Gмт, December 28 (fig. 12). This pattern indicated an area of strong west-northwest and west winds from $45^{\circ}$ $\mathrm{N}$. to $60^{\circ} \mathrm{N}$. and from $120^{\circ} \mathrm{W}$. to $60^{\circ} \mathrm{W}$. with a $500-\mathrm{mb}$. trough extending from the Great Lakes southwestward to the Pacific. As at sea level, high pressure prevailed at 500-mb. over the eastern Pacific with a north-south ridge at about $145^{\circ} \mathrm{W}$. and another pushing eastward at about $40^{\circ} \mathrm{N}$.

\section{COMPARISON OF TWO ANTICYCLONES}

A comparison of the behavior of these two anticyclones of December will be made with the aid of the surface and $500-\mathrm{mb}$. charts and the 1000- to 500-mb. thickness charts showing areas of advection. As pointed out, in the case of Echo the entire synoptic picture favored southward penetration. The depth of the surface Low, the extensive area covered by the cyclonic circulation to the east of Echo, the favorable elongation and eastward position of the 500-mb. Low, all contributed considerably to the southward steering of Echo. To the west of Echo there was a shift to lower index. The southerly winds of the $500-\mathrm{mb}$. Low in the Gulf of Alaska sent warm air over Alaska contributing to the building of the north-south ridge along the 120th meridian which maintained the necessary northwesterly flow to steer Echo southward.

In the case of Fox, temperatures $10^{\circ}-15^{\circ} \mathrm{C}$. colder at the surface and aloft in the area of its generation, very large 3-hourly pressure tendencies at $1830 \mathrm{GMT}$, December 28 south and west of the high axis, and no apparent block to southeastward motion, were tempting factors favoring a forecast of a cold outbreak. In the overall picture, however, the stage was not set for far southward penetration of Fox. The absence of a deep surface Low in the northeast United States was conspicuous. Lows had been weak and rapidly moving near the United StatesCanadian border. The much deeper $(15,300-\mathrm{ft}$.) $500-\mathrm{mb}$. Low which was farther west, $65^{\circ} \mathrm{N}$., $80^{\circ} \mathrm{W}$. (compare figs. 3 and 12), set up much strong west to east flow in the latitude of Fox's formation. The strong northwest winds on the western side of the $500-\mathrm{mb}$. Low accounted for the 45 -knot southeastward movement of Fox before it divided into two cells. In the west at this time a return to higher index and stronger westerly flow at higher latitudes accounted for a more easterly track of the main body of cold air associated with Fox. The Pacific 500-mb. Low was weak and too far west (fig. 12) to assist in building a ridge that would immediately move Fox southward. The

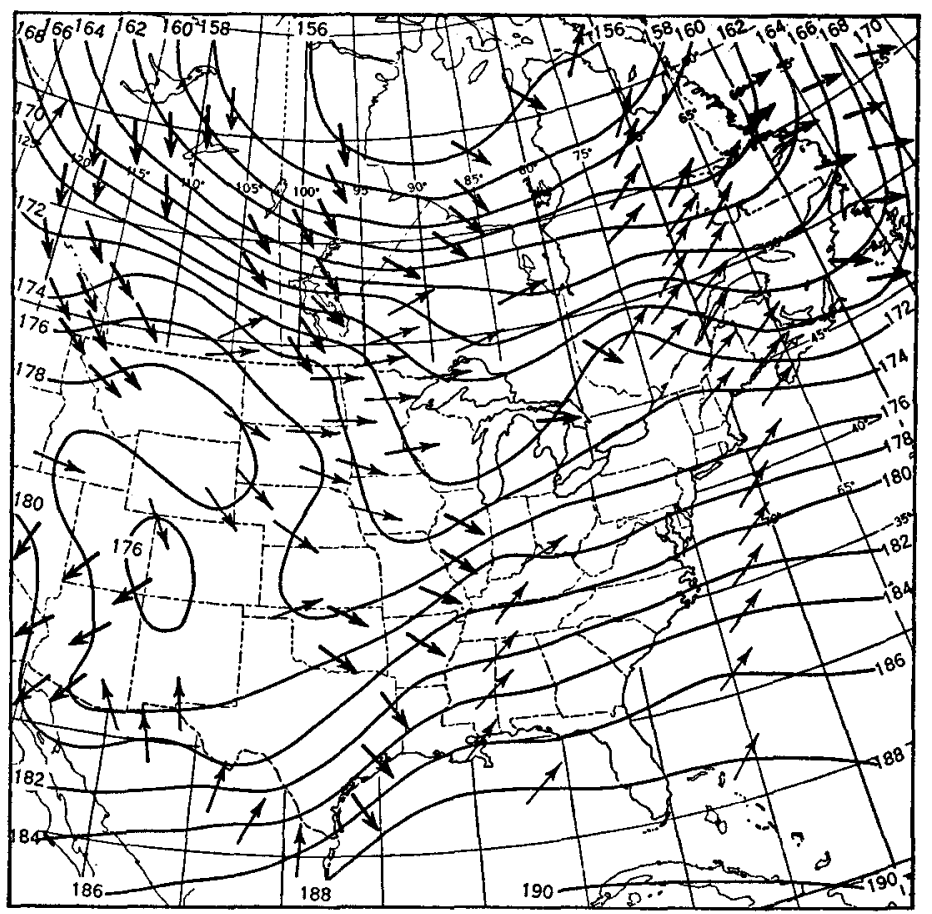

Figura 13,-1000- to 500-mb. thickness (labeled in hundreds of feet), $1500 \mathrm{amT}$, December 28,1953 , with advection arrows (thin shaft $=$ warm advection, thick shaft=cold advection). Compare with figure 7.

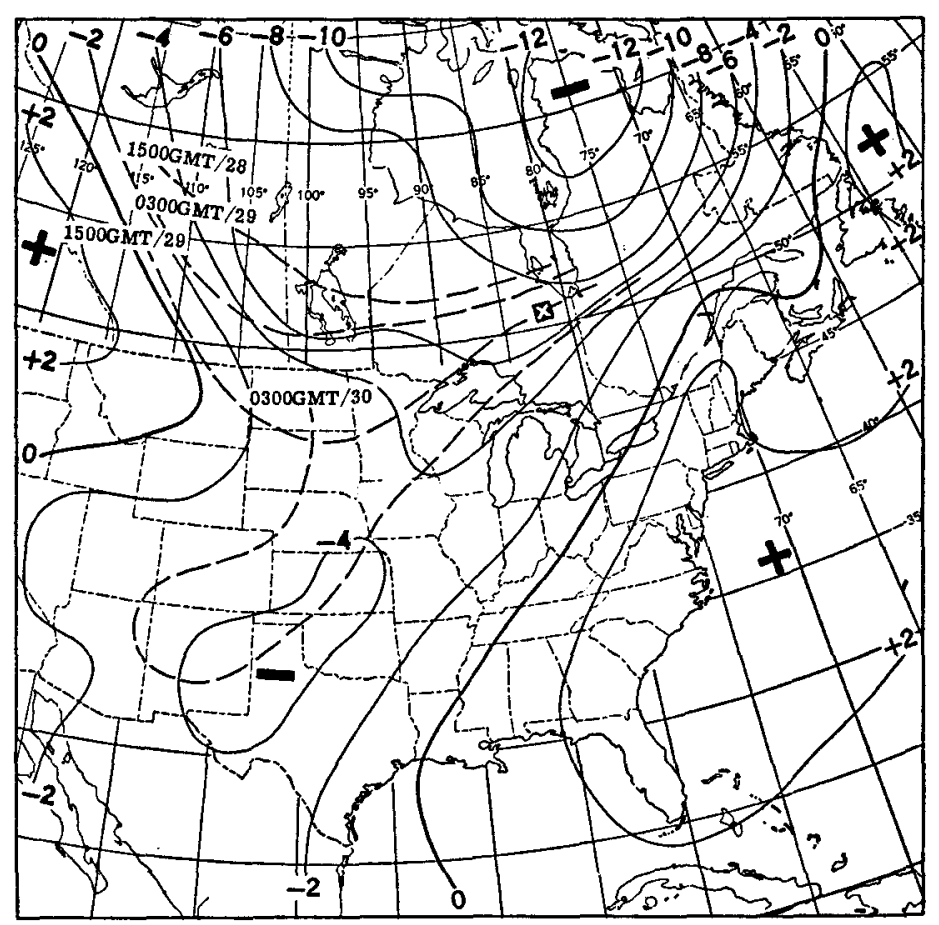

FiguRe 14.-Departure from normal 1000 to $500-\mathrm{mb}$. thickness (labeled in hundreds of feet) for $1500 \mathrm{GMT}$, December 30,1953 . " $X$ " marks surface position of Fox at this time. Heavy dashed lines represent the 12-hr. positions of the minus 400-ft. departure from normal contour from $1500 \mathrm{GMT}$ December 28 to $0300 \mathrm{GMT}$ December 30 inclusive. Compare with figure 9 and note the marked difference in orientation of the negative depar. ture area. 
high pressure was centered about $40^{\circ} \mathrm{N}$., $140^{\circ} \mathrm{W}$., but this ridge had much less amplitude than the one of December 18, and did not reach far enough north to give Fox a southward push. In fact, as the $500-\mathrm{mb}$. ridge of December 28 pushed eastward at lower latitudes $\left(40^{\circ} \mathrm{N}\right.$.), this flow aloft assisted the surface $\mathrm{mP}$ High in its eastward migration.

The advection arrows of figure 13 (compare with fig. 7) indicate a concentration of cold advection in western Canada. Steering of this area of cold advection with the $500-\mathrm{mb}$. flow would swing most of the cold air eastward along the Canadian border east of $90^{\circ} \mathrm{W}$.

A comparison of figures 9 and 14 illustrates the difference in southward penetration of cold air for the two periods discussed. The region of strong temperature con- trast in the case of Fox remained north of the United States (fig. 14) and the $-400-\mathrm{ft}$. departure contour reached southward only on the 0300 GMT December 30 chart.

\section{REFERENCES}

1. H. Wexler, "Formation of Polar Anticyclones", Monthly Weather Review, vol. 65, No. 6, June 1937, pp. 229-236.

2. R. W. James, "The Latitude Dependency in Cyclones and Anticyclones", Journal of Meteorology, vol. 9, No. 4, Aug. 1952, pp. 243-251.

3. H. Wexler, "Anticyclones", Compendium of Meteorology, American Meteorological Society, Boston, 1951, pp. 621-629. 